\title{
Probucol の高脂血症に対する用量の検討*
}

—II. 封筒法による多施設参加用量試験からみた単位有効量と有効反応率—

\begin{tabular}{|c|c|c|c|c|c|c|c|c|c|}
\hline 秦 & 㮦 哉** & 重 & 松 & & 洋** & 及 & 川 & 孝 & 光** \\
\hline 五 島 & 雄一郎** & 玉 & 地 & 寛 & 光** & 熊 & 谷 & & 朗** \\
\hline 藤 & 康** & 森 & & 晈 & 祐 $* *$ & 本 & 田 & 正 & 節** \\
\hline 那原 & 良 夫** & 川 & 村 & & 顕** & 岡 & 島 & 重 & 孝** \\
\hline 野 & 孝 徳** & 小 & 泉 & 和 & 生** & 有 & 賀 & & 光** \\
\hline 藤 & 重 明** & 小 & 林 & 康 & 弘** & 田 & 中 & & 男** \\
\hline
\end{tabular}

\section{I.はじめに}

われわれは，プロブコール Probucol† をわが国 に導入し，実用化するに際して，欧米で使用され ている 1 日 $1,000 \mathrm{mg}$ の用量が，体重や血清脂質 の平均水準が異なり, 食事の脂肪摂取量に差のあ る日本人に果してそのままで適量であるか否かを 検討する必要とある考えた.

そのために, プロブコールの欧米での使用量 1

日 $1,000 \mathrm{mg}$ に対して，導入薬剤の適量が，しば しばその $3 / 4$ 程度であるという過去の経験に照ら して，まず 1 日 $750 \mathrm{mg}$ といら用量を設定し，そ れら 2 用量でのプロブコールの臨床的有用性を比 較する試験を行った ${ }^{1)}$. 試験は, 多施設参加によ って集めた多数例に 2 用量を封筒法で無作為に割 りっけ, 血清脂質を集中測定する方式をとった ${ }^{1)}$. その結果, プロブコールは, 血清脂質の総コレ ステロール，トリグリセライド， HDL-コレステ ロールの 3 者をいずれも前值に比べて有意に低下 させるといら効果を示したが， 2 用量の間には有 意差がなく，用量効果関係がみられなかった。っ まり，1日 $750 \mathrm{mg}$ の用量で $1,000 \mathrm{mg}$ の用量と 同等の効果が得られる可能性が示された ${ }^{1,8)}$.

この研究では, プロブコールの 2 用量の効果を,

*1982年 2 月, 日本動脈硬化学会 昭和 56 年度冬季大 会において発表

** 慶応義塾大学医学部内科
薬剤の単位量がどれだけの効果を示したかを知る 指標としての単位有効量 ${ }^{2)}$ と，薬剤をある集団に 投与したときの有効例の出る頻度を示す指標とし ての有効反応率 ${ }^{3)}$ の考えで解析し， 2 用量間の効 果について, 比較検討を行った.

\section{II. 対象と方法}

この試験は，Table 1 に掲げる 11 施設の 18 名 の医師の共同研究として実施した. 対象例は, これらの施設に通院ないし入院中の患者で, 前観 察期間 4 週間のうちに空腹状態で少なくとも 2 回 測定した血清総コレステロールが $220 \mathrm{mg} / \mathrm{d} l$ 以上 ないしトリグリセライド $150 \mathrm{mg} / \mathrm{d} l$ 以上の例とし た. 対象として含めてよい高脂血症と除外すべき 高脂血症の種類についてはすでに記述した ${ }^{1)}$.

薬剂は, 白色無臭の錠剂で 1 錠中にプロブコー ル $250 \mathrm{mg}$ を含むものを使用した.

対象例に対するプロブコールの用量の割付けは, 封筒法により無作為に行った. すなわち, 各施設 の医師は, 前観察期の検查で治療の適応とみらる 患者があるたびに，あらかじめコントローラーが 用量を記入して密封した封筒を開け，カードに指 示された用量を処方した. $750 \mathrm{mg}$ の場合には朝 2 錠, 夕 1 錠, $1000 \mathrm{mg}$ の場合には朝夕各 2 錠と 2

† Probucol (商品名末定)：ダウケミカル日本 (株), 第 一製薬(株), 大塚製薬(株), 東京.

†† Probucol 臨床調查計画 (五島雄一郎, 熊谷朗編). 1980 
動脈硬化 Vol. 10 No. 6 February 1983

Table 1 Probucol の封筒法用量検討試験の参加施設および共同研究者

\begin{tabular}{|c|c|c|c|c|}
\hline 施 & 研究者名 & 施 設 名 & \multicolumn{2}{|c|}{ 研究者名 } \\
\hline 東海大学医学部病院 & 五島雄一郎*† & 済生 会 中 央 病 院 & 荻野 & 孝徳 \\
\hline & 玉地 寛光† & 稲 城市立 病 院 & 小泉 & 和正 \\
\hline 慶応義塾大学医学部病院 & 秦 臀哉† & 千葉大学医学部病院 & 熊谷 & 朗 \\
\hline & 重松＼cjkstart洋 & & 斎藤 & 康 \\
\hline & 及川 孝光 & 川崎製鉄千葉病院 & 有賀 & 光 ${ }^{2)}$ \\
\hline 立 川共済 病 院 & 森 皎祐 & & 佐藤 & 重明3) \\
\hline 国立東京第二病院 & $\begin{array}{l}\text { 本田 正節 } \\
\text { 与那原良夫 }\end{array}$ & 県 立 東 金 病 院 & 小林 & 康弘 \\
\hline 東京歯大市川病 院 & 川村＼cjkstart顕1) & & & \\
\hline 川崎市立井田病院 & 岡島 重孝 & 東京大学 医 学 部 & 田中 & 恒男**† \\
\hline
\end{tabular}

* 世話人, **コントローラー, † 小委員会委員, 1)現・伊勢慶応病院，2)現・国立習志野病院，3)現・鹿島労災病院
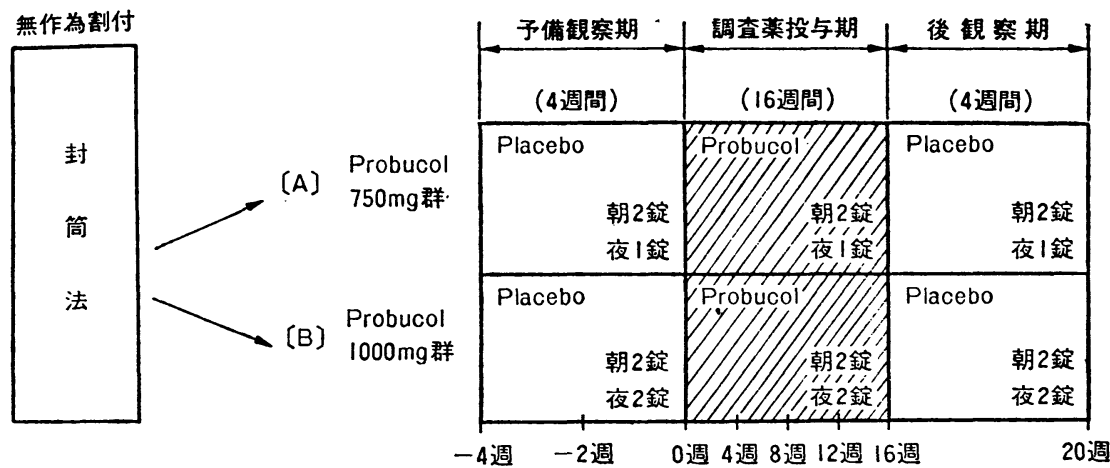

Fig. 1 Probucol 封筒法試験の用量設定試験の計画.

分服を指示した.

試験期間は，前観察期 4 週間，投薬期間 16 週 間，後観察期間 4 週間，計 24 週とした. 患者に は原則として 2 週ごとに来院を求め, 自覚症状, 服薬状況を問診し，身体所見を調べ，体重，血圧 を測定した．原則として 4 週ごとに空腹状態で採 血して血清脂質の測定を行い，少なくとも前後 2 回末梢血, 一般臨床化学検查, 検尿, 心電図検査 を行った. 血清脂質の総コレステロール，トリグ リセライド，HDL-コレステロールは，採血後分 離した血清の一部を検査センターに運び集中測定 した。その他の検査は，各施設で実施した。検査 の項目はすでに記載した1).

なお，試験期間中は食事療法についての指示内 容は変更しないこととした，血清脂質に影響を与 える薬剤の使用はしないこととし, 降圧剤, 精神 安定剤，消化剂を併用する場合は，期間中できる だけ使用量を一定にすることとした.
ここでは，プロブコールの血清脂質に対する効 果を, 薬剤の単位量 $(100 \mathrm{mg})$ が与える効果を表 す指標としての単位有効量 $\left.{ }^{2}\right)(\mu \mathrm{mg} / \mathrm{d} l / 100 \mathrm{mg})$ と 集団に㧤いて有効例の頻度を示す指標としての有 効反応率 3$)(\gamma \%)$ の 2 つの指標で解析を行った.

\section{III. 成 績}

この試験に参加した 11 施設において，プロブ コール 1 日 $750 \mathrm{mg}$ ないし $1,000 \mathrm{mg}$ の投与をうけ た症例は, 112 例 $(750 \mathrm{mg}$ 群 63 例, $1,000 \mathrm{mg}$ 群 49 例) であった。このうち除外例として 7 例 (750 $\mathrm{mg}$ 群 4 例, $1,000 \mathrm{mg}$ 群 3 例) と脱落例 が 5 例 (750 mg 群 4 例, $1,000 \mathrm{mg}$ 群 0 例) があり, 計 12 例 (750 mg 群 9 例， $1,000 \mathrm{mg}$ 群 3 例) を除いた 100 例 (750 mg 群 54 例, $1,000 \mathrm{mg}$ 群 46 例) が有 効性解析例であった (Fig. 2).

除外例ならびに脱落例の理由 はすでに記述し $た^{1}$ ). 有効性解析例の $750 \mathrm{mg}$ 群 54 例（男性 29 


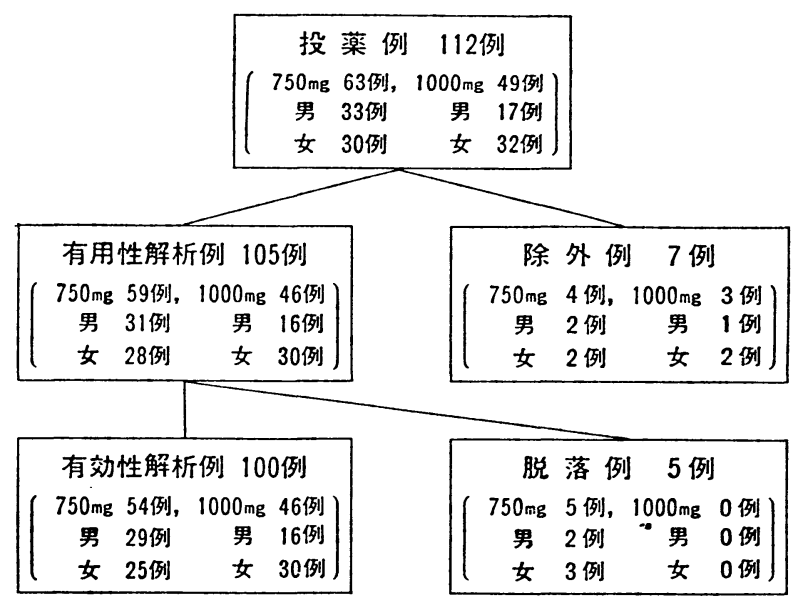

Fig. 2 Probucol 封筒法試験における対象例の内訳.

Table 2 Probucol の封筒法試験における各脂質に対する単位有効量と有効反応率

\begin{tabular}{lrrccccc}
\hline & $\begin{array}{c}\text { Dose } \\
(\mathrm{mg} / \mathrm{day})\end{array}$ & $\mathrm{n}$ & $\begin{array}{c}\text { 単位有効量 } \\
(\mathrm{mg} / \mathrm{dl} / 100 \mathrm{mg})\end{array}$ & $\begin{array}{c}\text { 基準単位有効量 } \\
(\mathrm{mg} / \mathrm{d} / / 100 \mathrm{mg})\end{array}$ & $\begin{array}{l}\text { 有効 } \\
\text { 有効: 無効例 }(\%)\end{array}$ & $\begin{array}{c}\text { 基隻反応率 } \\
(\%)\end{array}$ \\
\hline 総コレステロール & 750 & 42 & $4.5 \pm 2.9^{*}$ & 4.1 & $38: 4$ & $(91: 9)$ & $91: 9$ \\
& 1000 & 36 & $4.0 \pm 3.0$ & 3.9 & $34: 2$ & $(94: 6)$ & $95: 5$ \\
\hline トリグリセライド & 750 & 42 & $4.1 \pm 9.8$ & 4.1 & $28: 14$ & $(67: 33)$ & $74: 26$ \\
& 1000 & 37 & $2.7 \pm 5.5$ & 3.3 & $26: 11$ & $(70: 30)$ & $55: 45$ \\
\hline HDL-コレステロール & 750 & 42 & $1.0 \pm 0.7$ & 0.7 & $38: 4$ & $(9: 91)$ & $11: 89$ \\
& 1000 & 36 & $0.8 \pm 0.8$ & 0.4 & $31: 5$ & $(14: 86)$ & $19: 81$ \\
\hline
\end{tabular}

${ }^{*}$ Mean \pm SD

例, 女性 25 例) と $1,000 \mathrm{mg}$ 群 46 例（男性 16 例, 女性 30 例) の臨床背景には群間で差はみられなか った'.

有効性解析例のうち投薬後の測定值が少なくと も 3 回以上ある例について, 試験期間中の累積変 化量を実服薬量で割算して得られる単位有効量を 計算した ${ }^{2)}$. 各脂質の例数と計算值を示したのが, Table 2 の左半分である. 単位有効量が正の值に なった症例を有効例としたとき ${ }^{3)}$, 全対象例中で の有効例の割合と各重症度群での有効例の割合を Table 2 の右半分に示した.

この試験でプロブコールの $100 \mathrm{mg}$ 当りが示し た単位有効量は, 計算例全部の平均として $750 \mathrm{mg}$ 群において $4.5 \mathrm{mg} / \mathrm{d} l / 100 \mathrm{mg}$ (以下単位を省略す る), $1,000 \mathrm{mg}$ 群において 4.0 であった. トリグリ セライドについては, $750 \mathrm{mg}$ 群で 4.1, 1,000 mg 群で 2.7 であった. HDL-コレステロールについ ては, $750 \mathrm{mg}$ 群で $1.0,1,000 \mathrm{mg}$ 群で 0.8 であっ

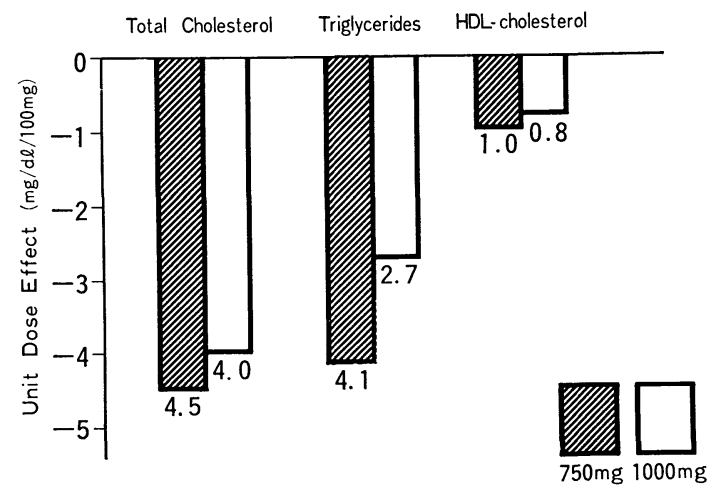

Fig. 3 Probucol の封筒法用量試験における単位有効量.

た (Fig. 3).

なお，単位有効量 $(\mathrm{y})$ と治療前值 $(\mathrm{x})$ の関係を 相関関係としてみたのが (Fig. 4)の上段である.

2 用量とも 3 脂質で $1 \%$ 水準の有意の相関がみら れた．総コレステロールでは $750 \mathrm{mg}$ 群について の回帰直線式は $\mathrm{y}=0.0301 \mathrm{x}-3.778,1,000 \mathrm{mg}$ 群 

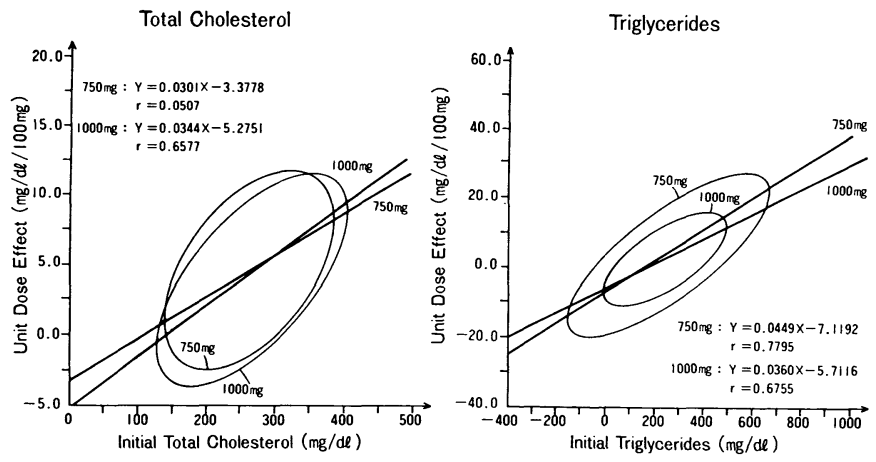

Total Cholesterol

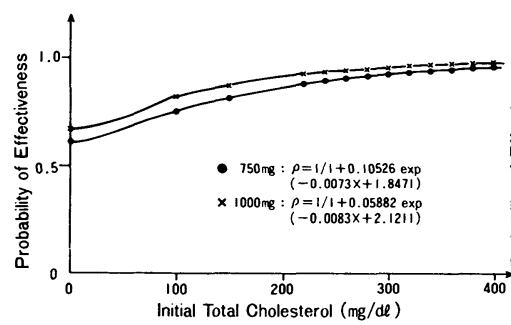

Triglycerides

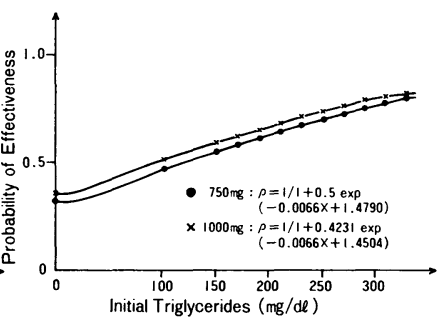

HDL-cholesterol

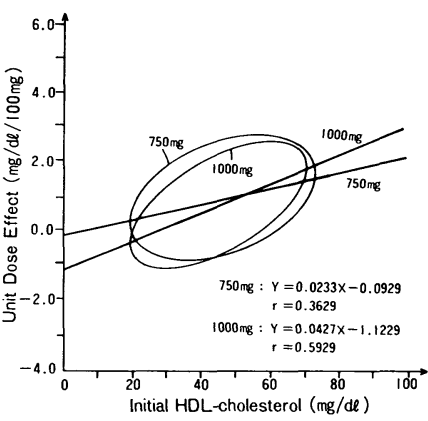

HDL-cholesterol

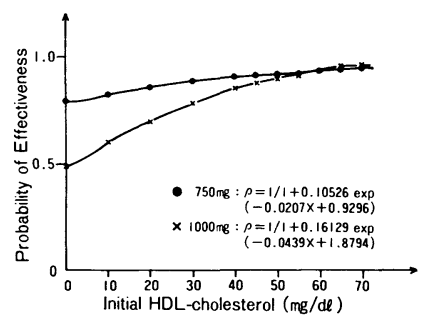

Fig. 4 Probucol 用量試験における前值と単位有効量甜よび反応率の定量的関係.

のそれは $\mathrm{y}=0.0344 \mathrm{x}-5.2751$, トリグリセライド ではそれぞれ $\mathrm{y}=0.0449 \mathrm{x}-7.1192$ ，および $\mathrm{y}=$ 0.0360x-5.7116, HDL-コレステロールでは $\mathrm{y}=$ $0.0233 \mathrm{x}-0.0929$ および $\mathrm{y}=0.0427 \mathrm{x}-1.1229$ であ った. 総コレステロールの前值が $260 \mathrm{mg} / \mathrm{d} l$ の単 位有効量は $750 \mathrm{mg}$ 群で 4.0, 1,000 mg 群で 3.7 であり，トリグリセライドの前值が $250 \mathrm{mg} / \mathrm{d} l$ の ときの単位有効量は，それぞれ 4.1 と 3.3, HDLコレステロールの前值が $35 \mathrm{mg} / \mathrm{d} l$ のをき単位 有效量は，それぞれ 0.7 と 0.4 であった. いずれ の脂質についても $750 \mathrm{mg}$ 投与の方が単位有効量 が大きかった。

プロブコール投与に対する有効例と無効例の割 合をみると, Fig. 5 のように総コレステロールに 関して $750 \mathrm{mg}$ 群で $91 \%$ に有効反応がみられ, 無 効例が $9 \%$ であった. $1,000 \mathrm{mg}$ 群では有効例が $94 \%$ ，無効例が 6\%であった.トリグリセライド については，上昇するものが有効例という定義に 従うと, $750 \mathrm{mg}$ 群で $9 \%$ が有効例, $91 \%$ が無効 例であり，1,000 mg 群で $14 \%$ が有効例， $86 \%$ が

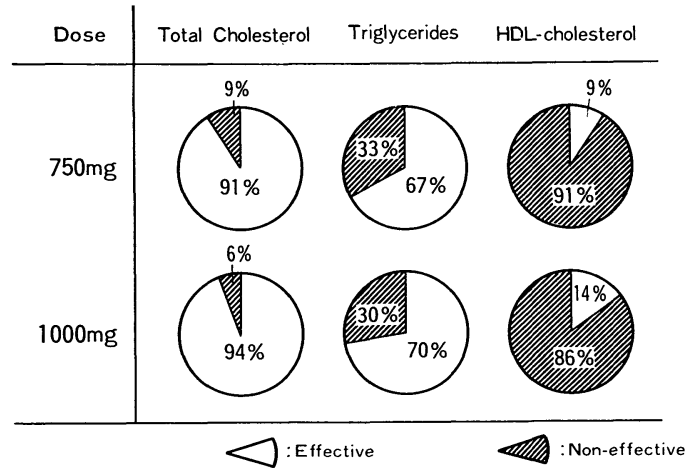

Fig. 5 Probucol の封筒法用量試験における有効反応率.

無効例であった. 有効反応率は， 3 脂質とも 750 $\mathrm{mg}$ 群より $1,000 \mathrm{mg}$ 群で大きかった.

反応率と前值の関係を判別関数で定量化し，口 ギスティック曲線で図示したのが Fig. 4 の下段 である. 総コレステロールの反応率 $\rho$ と前值 $(\mathrm{x})$ の関係は, $750 \mathrm{mg}$ 群で $\rho=1 / 1+0.10526 \exp$ $(-0.0073 \mathrm{x}+1.8471), \quad 1,000 \mathrm{mg}$ 群 で $\rho=1 / 1+$ $0.05882 \exp (-0.0083 \mathrm{x}+2.1211)$ であり, トリグ 
リセライドでは, それぞれ $\rho=1 / 1+0.500 \exp$ $(-0.0066 \mathrm{x}+1.4790)$ 打よび $\rho=1 / 1+0.4231 \exp$ $(-0.0066 \mathrm{x}+1.4504), \mathrm{HDL}-コ$ それぞれ $\rho=1 / 1+0.10526 \exp (-0.0207 \mathrm{x}+$ 0.9296) および $\rho=1 / 1+0.16129 \exp (-0.0439 \mathrm{x}+$ 1.8794) であった. 総コレステロールの前值が 260 $\mathrm{mg} / \mathrm{d} l$ のときの両群の反応率は, それぞれ 0.91 と 0.95 であり, トリグリセライドの前值が $250 \mathrm{mg} /$ $\mathrm{d} l$ のをき，同じく 0.74 と $0.55, \mathrm{HDL}$-コレス テロールの前值が $35 \mathrm{mg} / \mathrm{d} l$ のとき, それぞれ 0.89 と 0.81 であった.

\section{IV. 考案}

プロブコールの用量として, 欧米での 1 日用量 $1,000 \mathrm{mg}$ と, その $3 / 4$ 量としての $750 \mathrm{mg}$ の 2 用 量について, 多施設参加により確保された多数例 に封筒法による無作為割付けを行い, 血清脂質を 集中測定する方式で効果の比較試験を行った.こ こでは, その成績を各用量群での単位有効量と有 効反応率の指標を用いて解析した.

\section{1. 単位有効量からみた効果の比較}

プロブコールの単位有効量は, コレステロール について $750 \mathrm{mg}$ 群で $4.5,1,000 \mathrm{mg}$ 群で 4.0 で あった. トリグリセライドについてそれぞれ 4.1 と2.7, HDL-コレステロールについて同じく 1.0 と 0.8 であった. 3 脂質のいずれについても $750 \mathrm{mg}$ 投与の方が $1,000 \mathrm{mg}$ 使用時よりも単位有効量が 大きかった. このことは, $750 \mathrm{mg}$ 投与時の方が $1,000 \mathrm{mg}$ 投与時よりも薬剤の単位量が発揮して いる効果が大きいことを意味する. $1,000 \mathrm{mg}$ 投与 時には薬剤の少なくとも一部は血清脂質に対して 作用することなく代謝されたり，排泄されたりし ていることになる．体内に異物としての薬剤を入 れることは極少であることが望ましいという立場 からすれば, $250 \mathrm{mg}$ 用量が少なく, 単位有効量 が大きい 1 日750 mg の用量が望ましい用量とい うことができよう.

なお, 薬剤の単位有効量は, 用量のほかに対象 集団の重症度4) や前值の分布によって異なった值 をとりうる ${ }^{5,6)}$.したがって, プロブコールの単位 有効量を, この試験からだけで決定することは尚 早である，仮に用量を 1 日 $750 \mathrm{mg}$ とし，対象集
団の前值が総コレステロールで $260 \mathrm{mg} / \mathrm{d} l$, トリ グリセライド $250 \mathrm{mg} / \mathrm{d} l$, HDL-コレステロール 35 $\mathrm{mg} / \mathrm{d} l$ を血清脂質異常の代表值としたときのプロ ブコールの単位有効量 $(100 \mathrm{mg})$ を Fig. 4 の回帰 直線より求めると, 総コレステロールについて用 量別に 4.1 と 3.7, トリグリセライドについて 4.1 と 3.3 の低下力をもち, HDL-コレステロールに ついては $0.7 と 0.4$ の低下をおこすということに なる.これらの值は, プロブコールの真の単位有 効量を決定していく上で参考になる值であろう.

\section{2. 有効反応率よりみた効果について}

プロブコールの効果を有効反応率でみると総コ レステロールが $750 \mathrm{mg}$ 群と $1,000 \mathrm{mg}$ 群とでそ れぞれ $91 \%$ と $94 \%$ ，トリグリセライドについて $67 \%$ と 70\%, HDL-コレステロールについて $9 \%$ と $14 \%$ とわずかながらいずれの脂質についても $750 \mathrm{mg}$ 群よりも $1,000 \mathrm{mg}$ 群で有効率が高い結果 であった.これは単位有効量や前報での変化量, 変化率でみた成績とは対照的な結果であった. 有 効反応率のみが他の指標と異なる傾向を示すこと は, 他の試験でも経験されたことで7), これらの 2 つの概念が実用化され始めて日の浅い現在では, その真の意味は不明というほかがないが, 現在, 考えられる可能性は, 集団の中には用量が多いと き初めて反応を示し, 効果の現れる症例がありう るということであろう。こういう症例が実際には 前值の高い例なのか, あるいは正常值に近い例な のか, あるいはまた特殊な原疾患や合併症をもつ ものなのか今後解析する必要があろう.

単位有効量と同様に, 血清脂質異常の代表値と して総コレステロールが $260 \mathrm{mg} / \mathrm{d} l, \quad$ トリグリセ

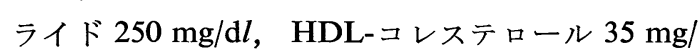
$\mathrm{d} l$ の水準での有効反応率を Fig. 4 のロギスティ ック曲線より求めると, 総コレステロールでは, 用量別に 91 と $95 \%$ ，トリグリセライドでは，74と $55 \%$ HDL-コレステロールでは 89 と $81 \%$ という 值が得られた．ただし，この試験での有効反応率 のロギスティック曲線は, どの脂質についても対 称形になっておらず8), これがプロブコールとい う薬剤の性質に由来することなのか, あるいはこ の試験の対象集団に限ったことなのか, プロブコ ールの有効反応率の決定には改めて検討すべき問 
題が含まれていることを付言しておきたい.

\section{3. 単位有効量と有効反応率からみたプロブコ ールの用量について}

このようにプロブコールの単位有効量と有効反 応率は, $750 \mathrm{mg}$ で単位有効量が大きく, $1,000 \mathrm{mg}$ でわずかながら有効反応率が大きいという結果で あった.つまり，プロブコールの単位有効量とい う縦の効果は, $750 \mathrm{mg}$ 投与時に大きく発揮され ており，集団の中での有効例の数という点からす ると $1,000 \mathrm{mg}$ 投与時の方が横の拡がりの大きい 効果がみられたわけである.

これらの縦横両方向の効果のいずれを重視して 至適用量を決めるかは, 薬剤の性質, 特に副作用の 頻度と程度, 薬価の問題などを含めてに綜合的見 地から選択されなければならないことはいうまで もない.しかし，この時点での印象として，プロ ブコールの単位有効量は, 集団の平均值として求 めた粗量としてみても，また異常代表值での值と してみても, 他の薬剤に比べて比較的大きいもの であり，いわゆる切れ味の感じられる薬剤の 1 つ である．この性格を考慮すると，効果の大小を問 わず広く多数の症例に使ってみるという使い方よ りも，ある範囲の症例に大きい効果を期待すると いう使い方の方が適切のように思われる. しかも $750 \mathrm{mg}$ 投与と $1,000 \mathrm{mg}$ 投与とで有効反応率の 差は，大差というほどのものでなかったこと，現 在その真の意義は未明とはいえプロブコールが HDL-コレステロールを低下させるといった点も 考慮すると，ここでは単位有効量の大きい用量が， より望ましい用量と判断される.

\section{V. まとめ}

プロブコールの用量設定のための最初の試験と して 1 日投与量 $750 \mathrm{mg}$ と $1,000 \mathrm{mg}$ の 2 用量の 臨床的有用性を多施設参加, 封筒法割付け, 血清 脂質集中測定の方式で比較する試験を行った.

1） 2 用量での血清脂質の総コレステロール， トリグリセライド，HDL-コレステロールに対す る効果を単位有効量と有効反応率の指標で解析し た.

2) 集団の平均值をとった粗単位有効量は, 総 コレステロールについて $750 \mathrm{mg}$ 投与で $4.5 \mathrm{mg} /$ $\mathrm{d} l / 100 \mathrm{mg}$ (以下単位略)， $1,000 \mathrm{mg}$ 投与で 4.0 であ った. トリグリセライドでは，それぞれ 4.1 と 2.7 , HDL-コレステロールでは同じく 1.0 と 0.8 であ った.

3) 同じく集団全体での有効例の割合をそのま ま取った有効反応率は，総コレステロールの 750

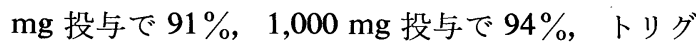
リセライドでそれぞれ $67 \%$ と 70\%，HDL-コレ ステロールで $9 \%$ と $14 \%$ であった.

4) 単位有効量と有効反応率の効果が, $750 \mathrm{mg}$ 投与と $1,000 \mathrm{mg}$ 投与とで異なる方向に大きいと いう結果になったが, 薬剤の性質, 有効反応率の 用量群間での差の值，HDL-コレステロールへの 作用などを考慮して，ここでは単位有効量の大き い用量が適当と考える意見を述べた。

終りに臨み,この試験のために薬剤を提供し, 協力し て下さったダウケミカル日本(秼)，第一製薬(株)，大塚製 薬(株)の関係者に謝意を表します.

\section{文献}

1）秦 㜊哉, 重松 洋, 及川孝光, 五島雄一郎, 田中 恒男，他：Probucol の高脂血症に対する用量の検 討一一封筒法による多施設参加用量試験からみた用 量と効果の関係 I.—. Geriat. Med., 20: 683-695 (1982).

2）秦 澱哉, 重松 洋, 都島基夫, 及川孝光, 山本 実, 山内喜夫, 広瀬信義, 宮崎和枝 : 血清脂質改善 剂の臨床評価法の検討—-II. 単位有効量の概念に ついて——. 臨床薬理, 11: 425-426 (1980).

3）秦 淂哉, 及川孝光：血清脂質改善剤の臨床評価法 の検討——IV. 有効反応率および無効反応率の概念 について一. 臨床薬理, 13 (投稿中) (1982).

4) 秦 㮦哉, 重松 洋: 成人高脂血症の重症度分類 一一高脂血症の診断, 治療方針ならびに治療法選択 の一基準として一，慶応医学，56：473-484 (1979).

5) 秦 臀哉: Pantethine の血清脂質異常に対する効 果一II. 107 施設 936 症例についての open study からみた重症度, 表現型, 合併症別の効果一 Geriat. Med., 20: 125-150 (1982).

6）秦 臀哉, 重松 洋, 都島基夫, 及川孝光, 山内喜 夫, 山本 実, 広瀬信義, 五島雄一郎, 渋谷 健, 他：Niceritrol の血清リポ蛋白異常に対する二重盲 検試験一IV. 重症度, 表現型, 合併症別の効 果——. Geriat. Med., 19: 1681-1688 (1981).

7) 秦 䔖哉, 八杉忠男, 葛谷文男, 末松俊彦, 古賀俊 逸, 斎藤 康, 山中 健, 他: $\gamma$-Oryzanol $の$ 高脂 血症に対する効果の検討一一用量設定のための多施 
Probucol の高脂血症に対する用量の検討

設協同による pilot study——. Geriat. Med., 19: 1813-1840 (1981).

8）秦 䔖哉, 重松 洋, 及川孝光, 五島雄一郎, 田中 恒男, 他: Probucol の高脂血症に対する用量の検
討——III. 封筒法による多施設参加用量試験からみ た性別, 重症度, 表現型, 合併症別の効果一一. 医 学と薬学 9: 255-277 (1983). 


\title{
Summary
}

\section{A Multi-central Dose Finding Study of Probucol on Hyperlipidemias -II. Unit Dose Effect and Effective Rate-}

\author{
Yoshiya Hata, Hiroshi Shigematsu, Takamitsu Oikawa, Yuichiro Goto, \\ Hiromitsu Tamachi, Akira KumagaYa, Yasushi Saito, Kosuke Mori, \\ Masanori Honda, Yoshio Yonahara, Akira Kawamura, Shigetaka OKaJima, \\ Takanori Ogino, Kazuo KoIzumi, Hikaru Aruga, Shigeaki Sato, \\ Yasuhiro KoBAYASHI and Tsuneo TANAKA* \\ *Multi-central Cooperative Study Group on Probucol
}

To determine the optimal dose of probucol in Japanese, we conducted a multi-central cooperative study on two doses of $750 \mathrm{mg}$ and $1000 \mathrm{mg}$ a day. The two doses were randomly allocated to 112 subjects with hyperlipidemias from 11 centers, out of whom 7 were excluded from the study because they were unsuited for the protocol, and 5 dropped out. The rest 100 cases completed the study, 54 being on $750 \mathrm{mg}$ and 46 on $1000 \mathrm{mg}$ a day. Their fasting blood samples were collected to a central laboratory and determined for serum total cholesterol, triglycerides and HDL-cholesterol.

The effect of probucol was analysed in this study in terms of the unit dose effect and the rate of effective case in each group. The unit dose effects were for total cholesterol $4.5 \mathrm{mg} / \mathrm{d} l / 100 \mathrm{mg}$ (the unit omitted hereafter) from $750 \mathrm{mg}$ group and 4.0 from $1000 \mathrm{mg}$ group. For triglycerides 4.1 from $750 \mathrm{mg}$ and $2.7 \mathrm{mg}$ from $1000 \mathrm{mg}$ group. For HDLcholesterol 1.0 from $750 \mathrm{mg}$ group and 0.8 from
$1000 \mathrm{mg}$ group, respectively.

The rate of effective case was for total cholesterol $91 \%$ in $750 \mathrm{mg}$ group and $94 \%$ in $1000 \mathrm{mg}$ group, for triglycerides $67 \%$ in $750 \mathrm{mg}$ and $70 \%$ in 1000 mg group, and for HDL-cholesterol $9 \%$ in $750 \mathrm{mg}$ group and $14 \%$ in $1000 \mathrm{mg}$ group, respectively.

These data indicated that probucol was more efficient in a daily dosis of $750 \mathrm{mg}$ in terms of the effect exerted by the unit amount of the drug, while it was more effective in $1000 \mathrm{mg}$ administration in terms of the numbers of cases whose unit dose effect became positive. Taking together, the magnitude of effects and the nature of drug, we considered that the unit dose effect was the more important determinant and that the daily dosis of $750 \mathrm{mg}$ was the favorable dose for use compared with $1000 \mathrm{mg}$ administration.

Key words: Probucol, Hyperlipidemia, Unit dose effect, Response rate. Optimal dose. 